October 2, 2007

WPOL-D-07-00072

1 Integrated Water Resources Management and Modeling at Multiple Spatial Scales in Jordan

David E. Rosenberg

Department of Civil and Environmental Engineering

Utah Water Research Laboratory

Utah State University

4110 Old Main Hill

Logan, UT 84322-4110 USA

david.rosenberg@usu.edu

Telephone: 001 (435) 797-8689

Fax: 001 (435) 797-1185

Submitted to Water Policy

September 12, 2007

Re-submitted October 2, 2007

Accepted: November 11, 2007

Manuscript \# WPOL-D-07-00072 


\title{
Integrated Water Resources Management and Modeling at Multiple Spatial Scales in Jordan
}

\begin{abstract}
Water shortages from intermittent public supplies are a major and expanding problem in the Hashemite Kingdom of Jordan. Yet individual users, utility managers, and government officials can improve access or cope with shortages in many ways. New supplies, more efficient use of existing resources, long-term investments to expand infrastructure and reduce leakage, and short-term measures to flexibly transfer, ration, or curtail some uses represent several different approaches, timings, and spatial scales for management. This paper reviews three separate systems analysis that use stochastic optimization with recourse. Analysis for individual residential users, the water utility serving 2.2 million residents in the capital Amman, and the entire kingdom comprising Amman and 11 other governorates identify complementary actions undertaken by individual users, utility managers, and government officials.
\end{abstract}

Keywords: systems analysis; water demand management; supply enhancement; water availability; integrated management; Jordan.

\section{Introduction}

More than one billion people have limited or intermittent access to improved water supplies. Limited or intermittent service can mean long distances to water sources, frequent or regular service disruptions, uncertain and inadequate sanitation, high incidence of water-borne diseases and child mortality, or environmental degradation. Shortages resulting from intermittent service also promote distrust in the utility service, force users to seek expensive alternative provisions, or require the utility to adopt irregular and more expensive operations. Any of these can spur public relations disasters for a water utility, service provider, or regulating governmental institutions.

Causes of shortages or intermittent service include supply rationing to meet demands; polluted sources; non-existent, leaky, or poorly-functioning infrastructure; belief that water is unfit to use or drink; contested water rights; or population growth exceeding the rate of new water resources and infrastructure development (Thompson et al. 2001). 
These causes span a commingled set of operational, engineering, planning, management, financial, social, political, and geographic factors.

Yet, many actions to improve water availability or cope with shortages are available to water utilities and their customers. Utilities can develop new water supplies or more efficiently use existing sources. Improving water use efficiency (often called water conservation or demand management) can include fixing leaks, reducing customers’ water use, altering the timing of water demands to better fit supply availability, or converting un-accounted-for or non-revenue water to revenue-generating sales. These sales can fund additional supply enhancement or conservation actions.

Many parties are involved in urban water supplies, from household users, to local water utilities, to regional or national governments. Different parties can undertake supply enhancement and water conservation actions at different spatial scales (Table 1). For example, a regional or national authority can negotiate water rights agreements and interbasin transfers with neighboring countries, reallocate supplies among water use sectors, institute water-efficient plumbing codes or import restrictions on inefficient water appliances such as toilets, showerheads, faucets, and laundry machines. A water utility or city water provider can develop new local surface or groundwater sources, desalinate nearby brackish waters or seawater, seed clouds to enhance runoff, publicize the financial and water savings to customers from water efficient appliances, provide monetary incentives to encourage customers to install efficient appliances, or ration water availability. Individual water users and customers also make many operational and management decisions. Households and individuals select their water sources, appliances, expenditures, and use behaviors. They decide numerous daily end-uses and invest capital to improve water quality and use efficiency. In Jordan, they connect to the public pipe network, drill private wells, catch rainwater, reuse grey-water, purchase from vendors, borrow from neighbors, treat water at home, expand onsite storage capacity, install water efficient appliances, alter landscape or irrigation technology, fix leaks, or modify water 
use behaviors during critical periods, including the timing, duration, and frequency to wash dishes, cars, shower, bathe, or irrigate landscaping.

The above actions also differ in their life span or period for which they are effective. Long-term actions such as building desalination plants, restructuring the distribution system to reduce physical leakage, or installing water efficient appliances require a onetime (and generally large) capital investment and establish infrastructure for supply or conservation. These actions must be taken well in advance of any actual supply provision or use reduction. Alternatively, short-term actions can be implemented when needed. Actions such as intra-district transfers, sector reallocations, or reducing shower or landscape irrigation time can flexibly respond to crisis or events as they occur and do not require advance planning. Selecting, combining, and timing actions while considering interdependencies and uncertainties are key aspects of planning decisions.

This paper develops the water policy implications of three systems analyses (Rosenberg 2007; Rosenberg and Lund in review; Rosenberg et al. 2007) for water management in Jordan and identifies complementary actions undertaken at multiple spatial scales by individual users, utility managers, and government officials. The paper is organized as follows. Section two reviews the stochastic programming technique underlying each systems analysis, section three summarizes results at each spatial scale, and section four discusses linkages, synergies, and conflicts among potential actions at each scale. Section five concludes.

\section{Systems analysis with stochastic optimization}

Considerable integrated water resources management (IWRM) work has focused on redressing causes of scarce water resources (Jaber and Mohsen 2001; Joench-Clausen and Fugl 2001; Scott et al. 2003; Thomas and Durham 2003; Wilchfort and Lund 1997; Wolf and Murakami 1995). The basic approach is: 
1. Identify a wide range of potential actions,

2. Characterize each action in terms of effectiveness, financial and perceived costs,

3. Describe interdependencies among actions,

4. Identify events and likelihoods for which the system must deliver water, and

5. Suggest a set of actions that minimize service costs or maximize benefits across all expected events.

Both centralized decision makers (government officials, water utility managers) and individual water users apply such a management approach (White et al. 1972).

The IWRM differs from traditional project evaluation such as cost-benefit analysis in two ways. First, IWRM involves stakeholders throughout the planning process-even at the beginning to identify and characterize potential actions. Second, actions are not mutually exclusive. A mix of actions may more effectively meet service objectives than a single or “magic bullet” option. Selecting, combining, and timing actions while considering interactions and uncertainties are key aspects of planning decisions.

\subsection{Stochastic optimization with recourse}

Managers can use systems analysis technique of stochastic optimization with recourse to identify a cost-effective mix of actions. The technique has seen extensive use to plan production, locate facilities, expand capacity, invest in energy, design chemical processes, manage water or the environment, and in agriculture, telecommunications, and finance (Sahinidis 2004; Sen and Higle 1999). Stochastic means something is not yet known (i.e., annual rainfall for next year), but has a pattern (i.e., averages $40 \mathrm{~cm}$ per year). Recourse permits corrective actions after more information is known (i.e., rainfall was $25 \mathrm{~cm}$ last year, so now we must...). The technique works as follows. 
Decisions are divided into two types. Long-term (first- or primary-stage) decisions are made before the stochastic state is revealed. After the state is known, short-term (secondary- or recourse-stage) decisions are then implemented to respond to the remaining shortfall. Short-term decisions apply only to the particular state. Figure 1 shows the decision tree structure.

For shortage management, stochastic states are shortage or water availability events with each event described by a shortage or availability level (water volume) and probability (occurrence likelihood). Together, long-term actions plus sets of short-term actions for each event constitute a decision portfolio or mix of actions to respond to shortages.

At the household and city scales, the optimal portfolio minimizes capital costs to implement long-term actions plus expected operational costs to implement short-term actions in each event. Expected operational costs are event-specific costs and are weighted by each event's probability. The optimal portfolio must meet the shortages for each event and respect upper limits for each long-term action, upper limits for each shortterm action that are potentially increased or decreased based on interactions with other actions, and limits on use of storage, conveyance, treatment, reuse, and other infrastructure that apply to subsets of actions.

At the regional scale, the optimal portfolio maximizes expected net benefits. These expected net benefits are expected benefits and costs from short-term allocations and operations weighted by the event probability minus long-term capital costs. The regional portfolio also must obey constraints on mass balance, infrastructure use, social and political policies. Many commercial and public domain programs (including Excel) can solve stochastic programs to identify the optimal portfolio. 


\subsection{Model inputs and outputs}

In this work, model inputs are the costs, life spans, and effectiveness for each action. There are also shortage levels and probabilities for each event for which the system must adapt to deliver water. Additional inputs are particular to the spatial scale of application and include the interdependency matrix, sub-sets of actions that can meet various infrastructure capacity requirements, or benefits from water use.

The primary model outputs are the recommended set of long-term actions, sets of shortterm actions for each event, and expected costs (capital plus operational) associated with these actions. Secondary results include the reduced costs for actions (i.e., the cost reduction needed to make the action cost-effective) and shadow values for meeting shortage levels or respecting infrastructure capacities (i.e., the decrease in the expected annual costs were the requirement relaxed one unit). Optimization software produces these outputs simultaneously as part of the solution. Secondary results help answer several economic and policy questions.

\subsection{Model extensions for intermittent water systems}

Users accessing intermittent public water supplies adopt a wide range of alternative supply enhancement and conservation actions to cope with shortages (White et al. 1972). To accommodate this variety, we extend prior shortage management work (GarciaAlcubilla and Lund 2006; Lund 1995; Wilchfort and Lund 1997) in several ways.

First, the work considers many more potential management actions_-some 39, 23, and 20 potential management actions each at the household, utility, and regional scales.

Second, more potential actions means expanded interdependencies among potential actions. Adopting an action can either reduce or enhance the effectiveness of adopting one or more other actions. For example at the household scale, a user installing a toilet dual-flush mechanism would not install a low-flush toilet. A user purchasing a water- 
efficient automatic laundry machine would not also purchase a water-efficient semiautomatic machine. Also, a toilet displacement bag saves less water per flush after a household installs a low-flush toilet (and similarly for the water saved by decreasing shower or irrigation time after installing a low-flow showerhead or water-efficient landscape). Prior shortage management work has yet to include the first interaction, mutual exclusively, which can strongly constrain decisions. The second interaction type is often termed "demand hardening" to describe the relation between long- and short-term actions. Namely, that "as more [long-term] conservation measures are permanently placed, the effectiveness of short-term conservation measures decreases and their relative costs increase” (Lund 1995; Wilchfort and Lund 1997).

Third, the work disaggregates water use into separate uses that accommodate different water qualities. At the household scale, drinking and cooking, indoor health and hygiene, and outdoor uses require different water qualities. At the utility and regional scales, freshwater differs from wastewater treated for reuse by agriculture. Disaggregating uses permits accounting for the costs and volumetric losses (evaporative, leakage, brine, etc) from actions that enhance water quality (e.g., home reverse osmosis units) or reuse wastewater (e.g., collect grey-water to irrigate landscaping).

A fourth extension recognizes restrictions infrastructures impose on multiple actions simultaneously. For example, at the household scale, rooftop and other household storage limit both the water volume a household can draw from the public network and rainwater it can collect during a shortage event. (Storage capacity is also a household decision, so this limitation also represents another interdependency among actions). At the utility scale, treatment and conveyance capacities limit surface water use while wastewatertreatment capacity limits the ability for agricultural users to substitute treated-wastewater for freshwater. 
And finally, we embed many of the above features in regional water management model that maximizes net benefits for a variety of water uses in multiple, connected locations.

\subsection{Major limitations}

The limitations of stochastic optimization with recourse for shortage management are well described (Garcia-Alcubilla and Lund 2006; Lund 1995; Wilchfort and Lund 1997). Principal limitations and suggested workarounds are:

Expected value decisions. The objective function weights short-term action costs by the event probability to give an expected-value, risk-neutral decision criteria. However, households, utility managers, and government officials are generally risk-adverse. Risk aversion can be accommodated in two ways: i) revise upward probabilities for extreme shortage events (above their hydrologic likelihood), or ii) modify the objective function to minimize cost deviations.

Drought triggers. Stochastic programming is a planning tool to respond to recurrent and long duration shortages. However, for systems that face short, infrequent shortages of a few days or weeks duration, trigger rules may play a more critical role to optimize responses. Yet, once an event is triggered, a simplified optimization program that only considers recourses (i.e., existing long-term actions are given) can still help identify the optimal response.

Event independence. The approach assumes shortage events occur independent of one another, ignoring effects of event timing or sequence. This assumption neglects actions such as groundwater banking or seasonal storage that permit temporal water transfers among events (i.e., from wet to dry periods).

Cost minimization rather than benefit maximization. Shortage management minimizes costs subject to meeting specified shortage levels. It sidesteps the economic question of how much water to allocate to maximize social benefits? Or, to what extent should 
operators ration (restrict) supplies to cope with shortages? Yet benefits (such as the utility water users derive from increased availability) are elusive to specify. Specification is further complicated when users value different levels of reliability, face complex price structures for municipal water, and have already adopted alternative strategies to cope with existing rationing. However, maximizing benefits reduces to minimizing costs when benefits are constant or linear with respect to the volume of water use. The regional scale application maximizes benefits.

\section{Application at three spatial scales in Jordan}

This section summarizes results of integrated management and modeling method at three separate spatial scales in Jordan. These scales are for

- Individual residential water users (households) in the capital city, Amman (Rosenberg et al. 2007),

- The Amman water utility serving approximately 2.2 million people (Rosenberg and Lund in review), and

- The region / nation comprising Amman and 11 other governorates (Rosenberg 2007, chapter 6).

The three applications show that the same method can be applied at different spatial scales with little structural modification.

\subsection{Situation in Jordan}

In Jordan, virtually all IWRM work has focused only on action identification and characterization (Abu Qdais and Batayneh 2002; Alkhaddar et al. 2005; Al-Salihi and Himmo 2003; Al-Weshah 1992; Jaber and Mohsen 2001; Scott et al. 2003; Taha and Magiera 2003). Little prior work has considered a comprehensive set of actions for 
intermittent systems or identified potential synergies or conflicts among actions taken at different spatial scales. Jordan is an interesting and relevant example for several reasons:

Chronic shortages. Water availability in Jordan is extremely limited. Annual consumption of 1 billion cubic meters (BCM) per year far surpasses annual renewable freshwater surface and groundwater supplies of 850 million cubic meters (MCM) per year (groundwater overdraft covers the deficit). With 5.4 million persons (2004) and water use split nearly $69 \%, 27 \%$, and $4 \%$, respectively, among agricultural, urban, and industrial uses (Abu Qdais and Batayneh 2002; Alkhaddar et al. 2005), water availability averages approximately $167 \mathrm{~m}^{3}$ per capita per year, but urban water use is only 22 to 36 $\mathrm{m}^{3}$ per capita per year (60 - 100 liters per capita per day) (Al-Salihi and Himmo 2003; Hussein 2002; Scott et al. 2003). Low per-capita water use is enforced through a strict regime of availability rationing, with water commonly available through the municipal network for 12 to 60 hours per week (Abu-Shams and Rabadi 2003).

Expanding shortages. Jordan's population is also growing at 2\% to 3\% per year. New water supplies are expensive, distant, or difficult to bring online. Therefore, chronic shortages and limited availability will likely worsen.

\subsection{Systems analysis for individual water users}

A systems analysis for individual water users in an intermittent supply system considers numerous interdependent water user behaviors (Rosenberg et al. 2007). Some 39 potential household actions include conservation, improving local storage or water quality, accessing sources having variable costs, availabilities, reliabilities, and qualities, and modifying behaviors (shower time, wash frequency, landscape irrigation, etc.) to reduce water use. An optimization program suggests the mix of actions a user should adopt to reduce expected water management costs given a probability distribution of piped water availability and action interdependencies such as demand hardening, supply enhancement, and mutual exclusivity. Monte-Carlo simulations show average citywide 
effects and distributions of customer responses, including piped water use. Table 2 shows the likely market penetration rates and associated water savings for several promising conservation actions. Significant water savings associated with low adoption rates indicate:

- Households differ in their abilities to conserve water.

- Targeted campaigns can save significant water and money with reduced effort

- Target installations of water-efficient appliances to households that will save the most \$\$ and water-households most likely to adopt.

Parametrically changing model parameters allows inferring potential economic effects for several water availability, pricing, and conservation efforts that we do not discuss here. Overall, systems analysis helps model and understand several complexities and impacts of water user behaviors and show that users have financial and other incentives to implement water conservation actions.

\subsection{Modeling for the city of Amman}

At the city scale, a stochastic program identifies the cost-effective mix of new supply and conservation actions to improve water availability to customers (Rosenberg and Lund, in review). The stochastic mixed-integer optimization program considers a mix of some 23 long- and short-term new supply and conservation actions. These actions include supply enhancement measures such as expanding wastewater treatment and reuse, developing new surface and groundwater supplies, expanding pumping and conveyance capacity from the Jordan valley, or desalinating brackish or seawater. On the water conservation side, options such as restructuring the pipe network, detecting and repairing leaks, targeting installation of water efficient appliances to customers who will save the most water and money, offering rebates for verified installations of said appliances, re-pricing water, disconnecting illegal customers, restricting outdoor water uses, retrofitting under- 
registering meters, or rationing can, respectively, curtail real losses, billed use, and apparent losses.

Alternative robust, grey-number, and best/worst case formulations systematically explore implications of uncertainties in action costs, life spans, water volumes gained or saved, shortage levels, and shortage probabilities.

Model results suggest four strategies to help Amman managers cope with shortages:

1. Conserve water now. Reduce physical leakage, target awareness to select customers to install water efficient appliances, and offer rebates to motivate other customers to follow suit. Water savings should grow over time at little added cost as demand increases.

2. Delay implementing mega projects for new supplies such as desalinating the brackish Zara-Ma'een waters and pumping the Disi aquifer to later years,

3. Significantly delay desalinating seawater (Red-Dead Canal) given the availability of cheaper new supplies and alternatives to reduce billed water use, physical, and accounting losses.

4. Build the Zara-Ma'een project as the low-cost option to increase water availability to customers.

Overall, the city-scale analysis shows that shortages pose a major and growing problem in Amman. Addressing shortages will require significant capital investments including for conservation. Increasing water availability to customers will require still further investments. 


\subsection{Modeling for the region / nation}

At the regional scale, we extend a deterministic, non-linear, single-year Water Allocation System model for all of Jordan (Fisher et al. 2005) to include water use efficiency, stochastic water availability, and long-term infrastructure expansions and conservation programs (Rosenberg 2007, chapter 6). The regional hydro-economic model includes demand shifts from non-price water use efficiency improvements as input parameters and decision variables. We include efficiency by shifting the demand curve that describes user benefits. We lower demand for actual water use but still count the benefits associated with maintaining the level of water related service. Water efficient appliances and technologies allow users to do the same with less water (or do more with the same water).

Stochastic non-linear programming then jointly identifies infrastructure expansions and operational allocations under variable water availability. We present a detailed application for Jordan's 12 governorates. It considers water use efficiency, leak reduction in the distribution system, surface and groundwater development, seawater desalination, conveyance, and wastewater treatment projects.

Application of the integrated regional water model in Jordan shows:

1. Water use efficiency in the urban sector can generate significant benefits with small capital investments. Benefits match gains from infrastructure projects and delay the need for them. The findings also suggest that the Jordan Ministry of Water and Irrigation should promote and encourage water use efficiency.

2. Rationing and conjunctive use operations are economical responses to stochastic water availability.

3. A broad mix of other infrastructure expansions projects and leak reduction programs can substitute for and forestall desalination in Aqaba and Balqa. 
4. The Disi carrier to Amman should include a large branch to Karak, and

5. Impending water scarcities in Zarqa, Ajloun, and Tafelah can be better managed by increasing conveyance from the neighboring districts of Mafraq, Irbid, and Ma'an where water has a lower economic use or is more available.

Overall, the analysis shows that a growing population and expanding water uses will significantly increase costs and competition for water. However, a broad mix of supply, infrastructure expansions, and conservation programs can mitigate these effects. Implementing these actions will require large capital investments. But the expected benefits should be larger still.

\section{Discussion}

In addition to the recommended actions to improve water availability, systems analyses at household, city, and regional scales has yielded contributions for water conservation planning, water use estimation, uncertainty propagation, and applied engineering, economics, and operations research. Contributions include:

At the household scale:

- New analytical and numerical approaches to estimate the distribution of water saved when a household adopts a conservation action,

- Ability to integrate source, availability, quality, local storage, costs, conservation, and user behaviors to estimate household water use,

- An empirically tested estimate for the distribution of water use among customers in Amman, while 
- Simultaneously predicting (i) adoption rates for conservation technologies, (ii) water use response to changes in water prices plus other factors, and (iii) household willingness-to-pay to avoid shortages.

At the city scale, modeling:

- Integrates multiple supply and conservation options with uncertainties, and

- Yields consistent results with different approaches to handle parameter uncertainties, however,

From regional scale work, we can now:

- Represent non-price shifts in demand from water use efficiency in a hydroeconomic model,

- Integrate effects of user and utility actions identified at narrow spatial scales, and

- Include infrastructure expansions and conservation program decisions along with stochastic water availability.

Combined, the above efforts also identify complementary actions taken by actors at different scales. We now discuss the complementary scales for action.

\subsection{Complementary scales for action}

Several promising management actions summarized above are implemented at several scales. In particular, conservation appears repeatedly. Individual households-on their own accord - have financial incentives to install water efficient appliances. Further, city programs to encourage or subsidize households to install water efficient appliances represent a cost-effective option for the city to cope with shortages. Also, targeted installations of water efficient appliances all across Jordan will generate substantial regional benefits. These benefits can be used to fund or justify national government 
efforts to develop and enforce water efficient plumbing codes, better label appliance water use (so customers can make better-informed purchases), or restrict the manufacture or import of inefficient water-use appliances.

Table 3 organizes the promising options from each scale to better illustrate the complementary scales for action. Placement in Table 3 shows both who initiates / suggests the action (row header) and who implements the action (column header) to procure the additional water or reduce use. For example, the upper-right box shows the national government finds it beneficial to develop water efficient plumbing codes, restrict the manufacture and import of water wasting appliances, and offer tax incentives to customers who install water-efficient appliances. However, these regional initiated actions only reduce water use when individual water users purchase and install water efficient appliances. But, scrolling down the User column shows that the city also finds it beneficial to offer water audits to recommend water-efficient purchases for users or rebates to encourage those purchases. Further, users find benefit to install water efficient appliances and landscaping. These complementary listings illustrate the linkages across scales. Linkages are bi-directional and work both from the (i) top-down (as centralized command and control management described above), and (ii) bottom-up (as grass roots lobbying or organization). For example, users who see benefits to install water-efficient appliances can motivate their friends or family to likewise adopt or lobby or otherwise organize to encourage decision makers at city or regional scale help make those appliances more widely available.

\subsection{Further work}

The systems analyses work presented herein identifies numerous promising actions and complementary scales for implementation. Additional work is needed to better promote and disseminate promising options and verify their benefits. 
For example, household surveys reveal that Amman residents can list conservation options, but lack specific knowledge such as what devices are water efficient, where they are purchased, their costs, how they are installed, or what benefits they might derive from them. More public awareness, skill development and motivation are needed to make targeted conservation programs successful.

We must also verify that water savings estimated herein translate to actual water savings when users install water efficient appliances. Verification first requires estimating water savings for individual households then monitoring households' aggregate and disaggregated water use before and after installation. A variety of non-intrusive, passive equipment is available to monitor components of household water use (Mayer et al. 1999; Vickers 2001).

At the city scale, improved employee accountability will help make efforts such as water audits for customers, rebates for installation of water efficient appliances, water meter retrofits, improved meter reading and billing effective and long-lasting. City and Regional scale stochastic modeling should also better represent water storage (both surface- and groundwater) across the stochastic water-availability events (inter-annual transfers). Marques (2004) includes inter-temporal transfers but does so by assuming groundwater storage capacity is very large compared to operational storage levels. This approach will not work in Jordan where surface and groundwater levels often hit the physical storage limits.

At the regional scale, further systems analyses should focus to resolve optimal sequencing of infrastructure capacity expansion and conservation program development over time with uncertain but growing demands. Optimal staging and timing can help identify when to start mega-supply projects like the Disi Aquifer or Red-Dead Canal, particularly since these projects have long (10+ year) lead times. Manne (1961), Bean et. al (1992), and others outline frameworks to examine project staging with uncertain 
demand. Additional important areas for regional study include optimal water management for environmental purposes, use of non-renewable resources (such as fossil groundwater), and integrated multi-objective management.

Finally, the systems analyses focus on water supply and conservation for urban water users. In Jordan and many other places, agricultural water use is a large component of the regional water budget (70\% in Jordan) and agricultural water conservation should present many promising new options. Much more research, modeling, applications, and verification are needed in this area.

\section{Conclusions}

Water shortages in Jordan are a major and growing problem. Water availability is usually just 12 to 72 hours per week yet there are several dozen or more potential options to improve availability. What actions should individual households, the Amman water utility, and the national government take to reduce shortages or improve system performance?

This paper summarizes three systems analyses that identify promising actions to address shortages at different spatial scales. The systems analysis at each scale integrates diverse options including new supplies, conservation to more efficiently use existing supplies or alter the timing of uses to make them better coincide with supply availability, and improving the institutional and regulatory environments to encourage new supply or conservation efforts. The analyses also consider long- and short-term investments, multiple water qualities for different uses, and uncertainties in all of the above including in action costs, life spans, effectiveness, water availabilities, reliabilities, and user behaviors. 
The analysis was repeated separately at three scales for individual households, the city of Amman, and all of Jordan. Promising actions identified at the household scale were included in the option mix for city and similarly at the regional scale.

Overall, this work shows that modeling can provide policy insights to integrate multiple source, reliability, conservation options, quality, costs, and explicit uncertainties to estimate water use and potential savings from adopting water efficient use practices. Integrating these multiple factors in a systems analysis further identifies promising actions to improve water availability in the face of shortages. Applications at different scales show multiple, complementary options for individual Jordanian households, the city of Amman, and region to improve water availability. Among these, urban water conservation - both reducing the leakage in the distribution system and motivating select households to install water efficient appliances-is very promising and should generate significant regional benefits. However, to improve availability, Jordan will require significant water sector investments over the next 20 years-more than \$US 3 billion or about $10 \%$ of Jordan's annual gross domestic product.

\section{Literature cited}

Abu Qdais, H. A., and Batayneh, F. (2002). "The Role of Desalination in Bridging the Water Gap in Jordan." Desalination, 150(2), 99-106.

Abu-Shams, I., and Rabadi, A. (2003). "The strategy of restructuring and rehabilitating the greater Amman water network." Water Resources Development, 19(2), 173183.

Alkhaddar, R. M., Sheehy, W. J. S., and Al-Ansari, N. (2005). "Jordan's Water Resources: Supply and Future Demand." Water International, 30(3), 294-303.

Al-Salihi, A. H., and Himmo, S. K. (2003). "Control and Management Study of Jordan's Water Resources." Water International, 28(1), 1-10.

Al-Weshah, R. A.-M. (1992). "Jordan's Water Resources: Technical Perspective." Water International, 17(3), 124-132.

Bean, J. C., Higle, J. L., and Smith, R. L. (1992). "Capacity Expansion under Stochastic Demands." Operations Research, 40, S210-S216.

Fisher, F. M., Huber-Lee, A., Amir, I., Arlosoroff, S., Eckstein, Z., Haddadin, M. J., Hamati, S. G., Jarrar, A. M., Jayyousi, A. F., Shamir, U., and Wesseling, H. (2005). Liquid Assets: An economic approach for water management and conflict 
resolution in the Middle East and beyond, Resources for the Future, Washington, D.C.

Garcia-Alcubilla, R., and Lund, J. R. (2006). "Derived willingness-to-pay for household water use with price and probabilistic supply." Journal of Water Resources Planning and Management-Asce, 132(6).

Hussein, I. A. J. (2002). "Water Planning in Jordan: Future Scenarios." Water International, 27(4), 468-475.

Jaber, J. O., and Mohsen, M. S. (2001). "Evaluation of non-conventional water resources supply in Jordan." Desalination, 136(1-3 SU), 83-92.

Joench-Clausen, T., and Fugl, J. (2001). "Firming up the Conceptual Basis of Integrated Water Resources Management." International Journal of Water Resources Development, 17(4), 501-510.

Lund, J. R. (1995). "Derived estimation of willingness to pay to avoid probabilistic shortage." Water Resources Research, 31(5), 1367-1372.

Manne, A. S. (1961). "Capacity Expansion and Probabilistic Growth." Econometrica, 29(4), 632-649.

Marques, G. (2004). "Economic Representation of Agricultural Activities in Water Resources Systems Engineering," PhD, University of California, Davis, Davis.

Mayer, P. W., DeOreo, W. B., Opitz, E. M., Kiefer, J. C., Davis, W. Y., Dziegielewski, B., and Nelson, J. O. (1999). "Residential End Uses of Water," American Water Works Association, Denver, Colorado. http://www.aquacraft.com/index.htm.

Rosenberg, D. E. (2007). "Integrated water management and modeling at multiple spatial scales," PhD, University of California, Davis, Davis.

Rosenberg, D. E., and Lund, J. R. (in review). "Modeling integrated water utility decisions with recourse and uncertainties." Water Resources Management.

Rosenberg, D. E., Tarawneh, T., Abdel-Khaleq, R., and Lund, J. R. (2007). "Modeling Integrated Water-User Decisions in Intermittent Supply Systems." Water Resources Research, 43(7), W07425.10.1029/2006WR005340.

Sahinidis, N. V. (2004). "Optimization under uncertainty: state-of-the-art and opportunities." Computers \& Chemical Engineering, 28(6-7), 971-983.

Scott, C. A., El-Haser, H., Hagan, R. E., and Hijazi, A. (2003). "Facing Water Scarcity in Jordan: Reuse, Demand Reduction, Energy, and Transboundary Approaches to Assure Future Water Supplies." Water International, 28(2), 209-216.

Sen, S., and Higle, J. L. (1999). "An introductory tutorial on stochastic linear programming models." Interfaces, 29(2), 33-61.

Taha, S., and Magiera, P. (2003). "National Water Master Plan: Water Resources in Jordan." Ministry of Water and Irrigation, Amman, Jordan. http://www.mwi.gov.jo/nwmp/NWMP/index.htm.

Thomas, J. S., and Durham, B. (2003). "Integrated Water Resource Management: looking at the whole picture." Desalination, 156(1-3), 21-28.

Thompson, J., Porras, I. T., Tumwine, J. K., Mujwahuzi, M. R., Katui-Katua, M., Johnstone, N., and Wood, L. (2001). "Drawers of Water II: Summary." International Institute for Environment and Development, London. http://www.iied.org/sarl/dow/pdf/summary.pdf.

Vickers, A. L. (2001). The handbook of water conservation, WaterPlow Press, Amherst, Massachusetts. www.waterplowpress.com. 
White, G. F., Bradley, D. J., and White, A. U. (1972). Drawers of Water, The University of Chicago Press, Chicago, IL.

Wilchfort, O., and Lund, J. R. (1997). "Shortage management modeling for urban water supply systems." Journal of Water Resources Planning and Management, 123(4), 250-258.

Wolf, A. T., and Murakami, M. (1995). "Techno-political decision making for water resources development: the Jordan River watershed." Water Resources Development, 11(2), 147-161. 


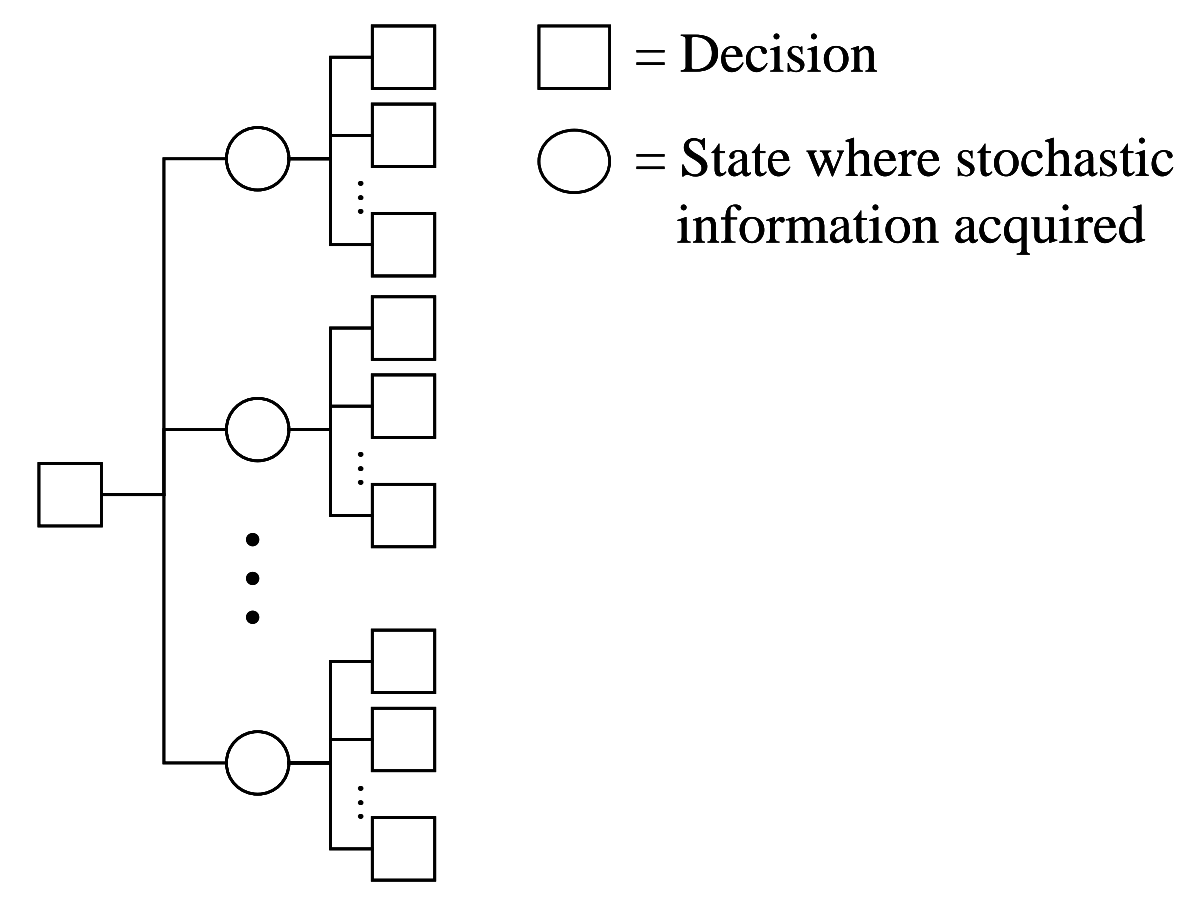

$1^{\text {st }}$
Stage

Figure 1. Decision tree for two-stage stochastic program with recourse. 


\section{Table 1. Potential Water Management Actions to Cope with Shortages in Jordan}

\begin{tabular}{|c|c|c|}
\hline Spatial Scale & New Supplies & Conservation \\
\hline $\begin{array}{l}\text { National or } \\
\text { Regional }\end{array}$ & $\begin{array}{l}\text { - Negotiate water rights } \\
\text { - Inter-basin transfers } \\
\text { - Secure aid to develop infrastructure }\end{array}$ & $\begin{array}{l}\text { - Import food, reallocate among water sectors } \\
\text { - Restrict imports on inefficient water appliances } \\
\text { - Establish water efficient plumbing codes } \\
\text { - Fund research to develop water efficient appliances } \\
\text { - Give tax credits to persons who install water-efficient } \\
\text { appliances }\end{array}$ \\
\hline $\begin{array}{l}\text { Utility or } \\
\text { District }\end{array}$ & $\begin{array}{l}\text { - Expand wastewater recycling and reuse } \\
\text { - Develop new surface and groundwater resources } \\
\text { - Seed clouds to enhance runoff } \\
\text { - Expand system storage, conveyance, and treatment } \\
\text { capacities } \\
\text { - Desalinate seawater or brackish waters } \\
\text { - Negotiate and exercise options to buy water during } \\
\text { droughts or shortages } \\
\text { - Purchase water on the spot market }\end{array}$ & $\begin{array}{l}\text { - Detection and repair distribution system leaks } \\
\text { - Optimize system flows } \\
\text { - Reduce system operating pressure } \\
\text { - Ration service } \\
\text { - Restrict certain water uses (outdoor) } \\
\text { - Reduce un-accounted for or illegal water use } \\
\text { - Re-price water } \\
\text { - Subsidize customers to install water-efficient } \\
\text { - } \text { appliances }\end{array}$ \\
\hline $\begin{array}{l}\text { Water User or } \\
\text { Customer }\end{array}$ & $\begin{array}{l}\text { - Develop alternative, local sources (rainwater } \\
\text { catchment, groundwater, springs) } \\
\text { - Increase draw from distribution network } \\
\text { - Collect and reuse grey-water } \\
\text { - Purchase from water venders } \\
\text { - Borrow or steal from others } \\
\text { - Boil or treat water to drink }\end{array}$ & $\begin{array}{l}\text { - Install water-efficient appliances } \\
\text { - Landscape or grow low-water consuming plants or } \\
\text { crops } \\
\text { - Detect and repair leaks } \\
\text { - Modify or reduce water-use behaviors }\end{array}$ \\
\hline
\end{tabular}




\section{Estimated adoption and water savings for households in Amman, Jordan}

\begin{tabular}{lcc}
\hline $\begin{array}{l}\text { Household } \\
\text { conservation } \\
\text { action }\end{array}$ & $\begin{array}{c}\text { Likely } \\
\text { adoption } \\
(\%)\end{array}$ & $\begin{array}{c}\text { Est. water } \\
\text { savings } \\
\text { (\% of use) }\end{array}$ \\
\hline Low-flow showerhead & $38.6 \%$ & $10.0 \%$ \\
Kitchen faucet aerator & $33.8 \%$ & $6.0 \%$ \\
Dual flush toilet & $24.8 \%$ & $5.0 \%$ \\
Collect rainwater & $18.0 \%$ & $1.8 \%$ \\
Greywater system & $19.6 \%$ & $1.6 \%$ \\
Xeriscape & $0.4 \%$ & $1.0 \%$ \\
Drip irrigate & $1.4 \%$ & $0.6 \%$ \\
Spray nozzle on hose & $4.0 \%$ & $0.5 \%$ \\
Automatic laundry & $0.0 \%$ & $0.0 \%$ \\
\hline Monte-Carlo simulations of 306,000 households \\
Current use is 47.4 TAF/year (58.5 MCM/year)
\end{tabular}


Table 3. Complementary Scales for Actions to Improve Water Availability in Jordan

\begin{tabular}{|c|c|c|c|c|}
\hline & \multicolumn{3}{|c|}{ Implements Action } \\
\hline & & National & City & Users \\
\hline \multirow{3}{*}{ 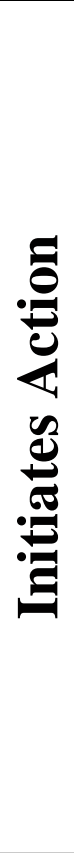 } & National & \begin{tabular}{|ll} 
г & Negotiate compacts \\
г & Fund research to \\
& develop water- \\
& efficient appliances
\end{tabular} & $\begin{array}{ll}\text { г Allocations + transfers } \\
\text { г Health, quality, and } \\
\text { water rights regulations } \\
\text { г Appoint officials } \\
\text { г } \text { Grants / loans }\end{array}$ & $\begin{array}{ll}\text { Г } & \text { Plumbing codes } \\
\text { Г } & \text { Import restrictions } \\
\text { 「 } & \text { Tax credits }\end{array}$ \\
\hline & City & $\begin{array}{l}\text { [ } \begin{array}{l}\text { Lobby } \\
\text { [ Advise national } \\
\text { authorities }\end{array} \\
\end{array}$ & 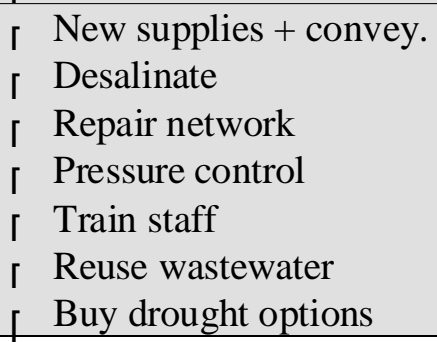 & $\begin{array}{ll}\text { г } & \text { Water audits } \\
\text { г } & \text { Water pricing } \\
\text { Г } & \text { Rebates to retrofit } \\
\text { Г } & \text { Awareness campaigns } \\
\text { г } & \text { Ration } \\
\text { г } & \text { Retrofit water meteres }\end{array}$ \\
\hline & Users & $\begin{array}{ll}\text { [ } & \text { Voting } \\
\text { [ } & \text { Political donations } \\
\text { [ } & \text { Political } \\
& \text { demonstrations }\end{array}$ & 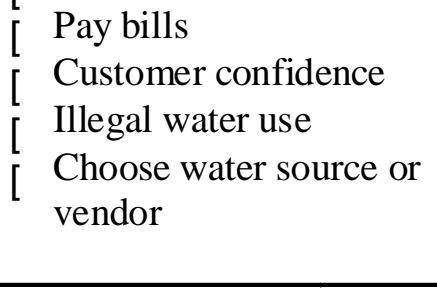 & $\begin{array}{ll}\text { 「 } & \begin{array}{l}\text { Install water efficient } \\
\text { appliances }\end{array} \\
\text { г } & \text { Xeriscape } \\
\text { 「 } & \text { Fix plumbing leaks } \\
\text { г } & \text { Change use behaviors } \\
\text { [ } & \text { Peer pressure } \\
\end{array}$ \\
\hline
\end{tabular}

Implies top - down management (command and control)

Implies bottom - up development (grass roots) 
